\title{
The Center of the Center Left
}

\author{
Carlo Baccetti
}

In the year 2000, Center leaning political parties and groups played a major role in the crowded scene of Italian politics. This is especially true in the case of parties which occupied the center space of the Center-Left, the focus of this analysis. Their political visibility notwithstanding, they persistently displayed confused tactics and contradictory goals. Leading protagonists and supporting actors disagreed over key questions including the very definition of "Center" and the political subjects it encompasses, and, with that, the meaning of the bloc's left flank. In fact, the groups of the Center-Left even debated the hyphen linking the two components of its name. ${ }^{1}$ In turn, a political force - the Democrats - was even created with the strategic goal of bypassing the Left/Right cleavage. The Democrats sought to unify the various forces that had joined the Ulivo's (Olive Tree) electoral cartel into a "democratic party," that was inspired by the American Democrats, down to the choice of a donkey as its symbol - hence their nickname "Asinello." Another element that makes it difficult to assign clear boundaries to the political center was that these groups of the center and Center-Left repeatedly took the "reformist" label. As a result, it is quite difficult to trace the boundaries of the semantic universes to which they refer and, in the end, it is often impossible to assess the true nature of the issues dividing political forces and of the stakes involved in particular choices or outcomes. The Center of the Center-Left is not easily analyzed. 


\section{A Difficult Year, Between Convergence and Divergence}

At the beginning of the year, three political actors led the CenterLeft side of the centrist stage: the Democrats, the Popolari (PPI), and the Unione democratica per la Repubblica (UDEUR). In September, three new actors appeared: a collective actor, the "Margherita" electoral coalition, and two individuals, CISL Secretary Sergio D’Antoni, and Antonio Di Pietro, who, left the Democrats to run 'solo' at the head of a movement called "Italia dei valori-Lista di Di Pietro." Other groups struggled to emerge or to stay alive. The SDI (Democratic Italian Socialists, a party born from the union of the PSDI, Schietroma's Social Democrats, and the SI, Ugo Intini's autonomist socialists) played an important supporting role, even as its spatial location, however, appeared to be ambiguous. No one could tell whether it belonged to the Center or the Left of the Center-Left. Events weakened yet another centrist actor, the Rinnovamento Italiano. During the thirteenth legislature, Lamberto Dini's fourth petal of the Margherita experienced the dissolution of both of its parliamentary groups, as elected officials left the Rinnovamento (seven deputies and six senators during the year). As a result, it became just another component of the ever-growing body of mixed groups in the Parliament and Senate. Rinnovamento Italiano stood out in the year 2000, as one of the most low-key protagonists in the Center arena, staying out of the limelight and appearing to be uninterested in distinguishing itself from its allies. The group was formed at the beginning of the legislature, when a variegated configuration of parliamentarians with significantly different views grouped under Dini's leadership primarily because of their common need to meet the electoral threshold. Over time, Rinnovamento Italiano lost many of its numerous components socialists, republicans, and, finally those who joined either the UDR-UDEUR or the Democrats. The small number who remained were the most cohesive and the least eager to define themselves as the ideologically secular and politically moderate centrist component par excellence of the Center-Left governmental coalition.

Overall, these political formations accounted for a relatively small share of the vote, 14.4 percent of those cast in the 2000 local elections. ${ }^{2}$ Table 1 describes the group's decomposition, recomposition, and overall fragmentation in parliament.

In 2000, the Center-Left arena followed an erratic trajectory of unity and fragmentation at different points in time. The diverse political groups and actors did not share clear goals. At best, we can identify two stages. The first phase was marked by repeated division and fragmentation and lasted from the beginning of the year 
Table 1. Changes in the Composition of Major Center and CenterLeft Parliamentary Groups and Components, in the Chamber and the Senate

\begin{tabular}{lllll}
\hline Groups & $\begin{array}{l}\text { Number of } \\
\text { Deputies } \\
\text { at the } \\
\text { Beginning } \\
\text { of the XIII } \\
\text { legislature }\end{array}$ & $\begin{array}{l}\text { Number of } \\
\text { Deputies } \\
\text { at the } \\
\text { Beginning } \\
\text { of } 2000\end{array}$ & $\begin{array}{l}\text { Number of } \\
\text { Senators } \\
\text { at the } \\
\text { Beginning } \\
\text { of the XIII } \\
\text { legislature }\end{array}$ & $\begin{array}{l}\text { Number of } \\
\text { Senators } \\
\text { at the } \\
\text { Beginning } \\
\text { of } 2000\end{array}$ \\
\hline $\begin{array}{l}\text { Popolari, } \\
\text { Democrats, }\end{array}$ & 67 & 58 & 31 & 31 \\
$\begin{array}{l}\text { Olive Tree } \\
\text { Democrats, }\end{array}$ & - & 21 & - & $5 \mathrm{a}$ \\
$\begin{array}{l}\text { Olive Tree } \\
\text { Lista Dini - }\end{array}$ & 26 & $7 \mathrm{~b}$ & 11 & $6 \mathrm{~b}$ \\
$\begin{array}{l}\text { Rinnovamento } \\
\text { Italiano }\end{array}$ & & & & 11 \\
$\begin{array}{l}\text { UDEUR } \\
\text { SDI }\end{array}$ & - & 21 & - & $3 \mathrm{c}$ \\
$\begin{array}{l}\text { UDR } \\
\text { Centro } \\
\text { Riformatore }\end{array}$ & - & $8 \mathrm{c}$ & & $5 \mathrm{e}$ \\
\hline
\end{tabular}

a Senators belonging to the mixed group's political component "The Democrats".

${ }^{\mathrm{b}}$ Deputies and senators belonging to the mixed groups' political component "Rinnovamento Italiano."

${ }^{\mathrm{c}}$ Deputies and senators belonging to the mixed groups' political component "Socialisti democratici italiani - SDI."

${ }^{\mathrm{d}}$ Members of a group created on 4 March 1998 by deputies coming from CCD, FI, and the mixed groups, and dissolved on 30 June 1999.

e Senators belonging to the mixed group's political component "Centro Riformatore," created in December 1999.

until the regional elections and the referenda in April and May. The second phase began before the August break and was characterized by efforts to bring about unity, even during this period.

Many key difficulties and uncertainties of the centrist constellation come from the fact that in the words of the actors on the Center-Left's Centrist stage, it was often the very boundaries of the arena itself that changed. The defining limits were set in an accordion-like pattern that made them vague and indistinguishable. As a result, the territory of the Center, and the groups that could or "ought to" be part of it, widened or shrank vis-à-vis the left, depending on specific circumstances and goals. 
The confusion and the division that thrived under the umbrella of centrist politics peaked between the end of 1999 and the beginning of 2000, after the forced resignation of the first D'Alema government. The "identity crisis" and SDI's search for visibility brought down the government, as the reformist forces positioned themselves between the Center and the Left, and demanded more autonomy in the coalition. They prepared to contest the hegemony of the DS, in the electoral and governing alliance.

The year 2000, thus, opened with the full gamut of centrist forces subject to a series of opposed pressures and tensions. At the same time, D'Alema managed to bring the governmental crisis to a rapid end by substituting Cossiga's followers with representatives of the Democrats, who had emerged as winners from the June 1999 European elections, thereby giving birth to his second ministry.

In January, the first centrifugal movement dissolved the "Trifoglio," the narrow-based alliance created by Boselli's SDI and the UPR (the small knot of parliamentarians who remained faithful to Cossiga after the break with Mastella) and the handful of PRI (Republican Party) parliamentarians led by Giorgio La Malfa. These three fragments of the centrist universe moved closer to each other, as they sought to block a possible renaissance of the Olive Tree "in the spirit of '96." At the Republican's March Chianciano Congress, they followed Secretary La Malfa's turnabout, moving closer to the Center-Right bloc, even as the party maintained support for the Amato government. ${ }^{3}$

Whereas the PRI's trajectory hardly affected the dynamics of the Center and the Center-Left, attention focused on the internal gyrations within the SDI. Party factions battled over their political location: were they in the Center or on the left of the Center-Left? Neither answered prevailed. In January, following Bettino Craxi's death, the party led by Enrico Boselli arrived at a critical turning point. When Cossiga's umpteenth u-turn brought what was left of his political creature closer to Berlusconi, Boselli decided to distance himself from the former head of state, thereby wrecking the Trifoglio. ${ }^{4}$

The need to arrive at some degree of unity prior to the 16 April regional elections momentarily and partially silenced the squabbling in the centrist constellation. The Center-Left focused on two political experiments, both viewed as tests of their future national ambitions: the regional list "Martinazzoli for president" in Lombardy and the regional list "Cacciari for the Veneto Region." losses of both candidates to the Center-Right elicited strategic changes on the national level. The Popolari led those who viewed Martinazzoli's loss as a clear warning against renewing the Olive Tree alliance. ${ }^{6}$ By contrast, some interpreted the performance of the 
Veneto as a sign for all of the Center-Left's centrists to unite. ${ }^{7}$ In particular, the list headed by Cacciari (which received 13.7 percent), became an important reference point for the Margherita, which was launched nationally at the end of the summer.

In addition, D'Alema's exit and the forced withdrawal of his candidacy as the Center-Left candidate at the national election also helped to lower the tone of the battles within the centrist arena and the entire majority. The search for a candidate to run against Berlusconi induced them to unite. With a potentially rancorous fight over D'Alema out of the way, they quickly moved to support Francesco Rutelli, jettisoning Prime Minister Amato. Only the SDI grumbled in discontent. This apparent unanimity did not actually diminish the terminological confusion and the real disagreements concerning strategic and organizational goals and the definition of the Center-Left's identity and strategic goals.

\section{The UDEUR's Pragmatic Faithfulness to the Center-Left}

The UDEUR emerged from the failed UDR. Led by the former president of the Republic, Francesco Cossiga, the UDR played a critical role in the demise of the Olive Tree. The effort to remove the centrist forces from the governing alliance helped to ensure the success of the prophecy of the DS's parliamentary leader, Fabio Mussi. Speaking on the very day in which the Prodi government fell ( 9 October 1998), Mussi predicted that the government crisis would cause the Ulivo's immediate "balkanization." Created with the goal of "dividing in order to unite," the UDR sought to detach the centrist forces from the two poles and to reunite them in a single moderate, catholic and liberal political formation. In time, Cossiga expected this group to become the Left's primary opponent. Due partly to the mercurial character of the former head of state, the UDR experienced numerous ups and downs: obscure and controversial episodes, splits, divisions and chain reactions. In turn, most of its members in parliament (who for the most part had followed Cossiga into the UDR from the Center-Right) left to join the UDEUR (Unione Democratica per l'Europa) on 20 March 1999. Founded and skillfully led by Clemente Mastella, this formation adopted a church steeple as its symbol. ${ }^{8}$

The new party has been a vocal and "irreversible" supporter of the Center-Left, even as many local representatives shifted to (or returned to) the Polo. The UDEUR encountered its most serious difficulties in Sicily, where five out of nine regional councilors as well as some of the party's most prominent regional officials promoted 
the "counter-quake" which, in the summer of 2000, led to the fall of the City Hall administration led by PDS mayor Capodicasa. They joined with five of the PPI's eight regional Sicilian deputies, including the party's regional Secretary, and all three regional deputies of Rinnovamento Italiano. Totò Cuffaro, a prominent UDEUR official, the party's national undersecretary, known as "mister 100,000 votes" and Mastella's powerful right hand man in Sicily ${ }^{9}$ - led them into the Polo. The Sicilian Centrists who abandoned the Center-Left created a new Center-Right majority that backed an administration led by Vincenzo Leanza, who had joined Forza Italia after having previously belonged to the $\mathrm{CD}, \mathrm{CCD}, \mathrm{CDU}$, UDR and last, UDEUR.

Declaring his faithfulness to Center-Left, even in the wake of his Sicilian troubles, Mastella played his political cards with considerable daring and determination. In the immediate aftermath of the regional elections, he made himself heard in the dispute with Bassolino concerning the composition of the Campania region administration, avoiding, thereby, another potentially disruptive episode for the party. "My party," Mastella implied, "may be small, but it makes a difference. We give the coalition another gear." The UDEUR led the effort to create a "federation of the Center," together with the Popolari and Rinnovamento Italiano. Mastella maintained that more organizational unity would give it more weight in choosing the electoral coalition's leader. Second, Mastella suggested that his successes and his party's organization would enable them to push aside their erstwhile allies, the PPI and Rinnovamento Italiano. Especially in the South where, according to Mastella, the center had reached 15 percent of the vote, he expected his party to serve as the locomotive that would pull the much-desired "federation" to victory.

\section{The Unraveling of the Center Territory: The Democrats}

Even the Democrats birth at the beginning of 1999 can be ascribed to the much feared "balkanization" of the Olive Tree. ${ }^{10}$ The Asinello's founders had the opposite intentions: they too wanted, if not "unity for the sake of it," at least to "divide in order to unite," and, therefore, to restore the Center-Left electoral coalition. Prodi sought to reach this goal by bringing the coalition to its logical conclusion and creating "the party of all the reformers." This decision followed Prodi's repeated rejections of the leadership of the PPI. It derived as well from his desire to punish D’Alema and Marini who had not supported his own government with sufficient conviction. Still, Prodi declared and vigorously pursued the goal ("competition 
is competition") of forcing the different segments of the Center-Left electoral alliance with Veltroni's faction of the DS and the creation of one big Olive Tree “democratic party.” Prime Minister D’Alema's clever countermove - the successful effort to name Prodi to head the European Commission - took Prodi out of Italian politics and removed the new formation's only authoritative leader. With Prodi in Brussels, his diverse lieutenants and followers battled each other for the political limelight.

Starting in the aftermath of its success at the 1999 European elections, the Asinello rapidly fell victim to a variety of tensions and pulls that reduced it to the size and the behavior of a small party. It became yet another small party of the Center, not the unifying force that would "leave all the small parties behind." So, in the course of 2000, the political formation Prodi had created led a troubled life. The hardest knot - and the one that was not cut was the rivalry between Di Pietro and Arturo Parisi. Di Pietro saw himself somehow as the dominus, the most authoritative member of the new political formation. He wanted to be recognized as its "true" leader. Prodi, however, chose Parisi to lead the party in his absence and to take his parliamentary seat in Bologna, transforming him from an advisor into a political leader.

The Democrats' first congress, the so-called Assembly of the Regions, which, in various localities, was prepared amidst quarrels and threats of expulsions, was held in Venice in early February. Sixty delegates elected by regional congresses participated. Parisi was elected president of the party and proposed lists of "reformist unity" at the regional elections. These candidates were to come together around "a shared program and the willingness of all their components, like us and together with us, to put themselves into question in order to arrive at a shared experience." The final explicit goal was to give life to a broader political subject, that is, a unique Center-Left party, the success of which required defeating simultaneously both the DS's "hegemony" and the PPI's "conservatism."

The Democrats, as opposed to the PPI and all the other Centrists, wanted nothing to do with a centrist party that would serve as a political counterweight to the DS within the alliance. Rather, they sought a single "Center-Left" party. Parisi, with a somewhat provocative intent, but believing that the path he proposed was in fact a viable one, actually invited the DS, on the occasion of their Turin congress, to "dissolve" into a large Center-Left federation along the lines proposed by Romano Prodi. The new leader also took the same stand with the Popolari. These former Christian Democrats had been strengthened by the failure of the referendum 
and the specter of a majoritarian system. Now, they invited the Democrats themselves, the UDEUR and Rinnovamento Italiano to accelerate the building of a centrist federation. "The invitation to participate in this project," replied Parisi, "should be addressed, we believe, to all available Center-Left forces, without exclusion." 11

As I have mentioned, however, this political preaching lacked credibility. After the crisis that followed D'Alema's resignation and the formation of the Amato Government, Massimo Cacciari, one of the Asinello's best known leaders, strongly criticized not only the way in which the crisis had been managed, but also the Democrats' overall behavior. The Asinello had been born with a call for the Center-Left to aggregate its components, "without utopias, starting from the local level." But instead of launching a unitary process toward a "unique party," said Cacciari at the end of April, it is just another "little party." The Democrats, insisted the former mayor of Venice, do not need a leader, but instead a collegial leadership composed of four or five people who would actually erase the past and seriously work to bring about the Center-Left federation. "In the Veneto and Lombardy regions we are absolutely ready to bring about, 'Together for Veneto,' or 'Together for Lombardy, and so on, with supporters of the Popolari, Democrats, Dini and others, but also, rapidly with the DS ... To be sure, we need some sympathy from the national bodies. If nothing else."12

Instead, the Democrats split internally into many currents, and they battled each other for governmental posts. In the aftermath of the regional elections, Di Pietro and his followers were already preparing to leave. As they did, they fired large caliber bullets at other people's authoritarianism and, above all, refused to support Amato - "Craxi's man" - as Prime Minister.

At the second Assembly of the Regions, held on 5-6 May in Rome, all the unsolved issues of identity burst into the open. Those who nurtured the ambitious project, of giving birth to nothing less than the unique democratic party, saw the outcome as a total failure. Such a party, it was hoped, would embody the bipolar ideal and, by eliminating the hyphen from the term "Center-Left," it would make the very Center disappear by tearing down boundaries and unifying the Olive Tree's territory. In the end, while Parisi in his speech to the Assembly admitted to "not minor difficulties, even within our ranks," a fight broke out between a handful of Di Pietro's supporters and a few followers of Parisi and Bordon. Bordon, who had cofounded the movement "L'Italia dei valori" with the former public prosecutor, had become the favorite target of $\mathrm{Di}$ Pietro's followers, who accused him of having sold out for a ministerial post. ${ }^{13}$ The Democrats were at each other's throats. 


\section{The PPI's Multifaceted Centrism}

For the PPI, the year 2000 began with the defeat of its attempt to prevent the entry of Forza Italia into the European Parliament's popular group (PPE). Furthermore, the birth of the Democrats exacerbated the Popolari's internal tensions and divisions. Many within the PPI criticized the party's Secretary, Castagnetti, whom they viewed as too favorable to the Olive Tree, and hence unable to protect and widen the party's "vital spaces." Castagnetti's leadership, his opponents claimed, would result in the PPI being eaten up either by the Democrats or by the Left. The Minister of Scientific Research, Ortensio Zecchino, an important representative of the PPI's pro-DeMita component in the Campania region and the principle spokesman of the supporters of "German-style" proportional representation, heavily attacked Castagnetti. According to Zecchino, Castagnetti was a Secretary "without a compass," who, since his election, had based his strategy entirely on finding an agreement with the Democrats, from whom he had received in return only "kicks...The truth is that Castagnetti is Prodi's orphan, exactly like Parisi. He always had in mind one and only one landing pad: the Olive tree, the Center-Left's only party." 14 Here too, we see the political fall-out of the Ulivo's collapse.

Disturbing signals of exits, real or only announced, followed, and led to fears of the party's imminent demise. At the beginning of 2000, the PPI still retained all thirty-one senators elected in 1996, but it had lost nine deputies, shrinking from 67 to 58 (see Table 1). ${ }^{15}$ In an apparent electoral free fall, the PPI went from 11.1 percent at the 1994 political elections, to 6.8 percent in 1996, to 4.2 percent at the 1999 European elections. "We look like a bonsai DC, with many fewer voters but with identical political rites," Castagnetti himself commented at the 11 February 2000 national Council. "It is a party of the dead," the minister Letta is said to have less mercifully commented at another PPI national council.

The election of Castagnetti to Marini's post in September of the previous year, in sum, certainly did not ease internal tensions nor did it manage to spur a revitalizing u-turn. Differences over the party's identity joined with clashes over patronage to form two competing blocs. One group sought to unify the center of the Center, the moderates who had come from the DC. They hoped to build a center inspired by a "Christian" worldview. This group struggled to aggregate PPI's, RI's and UDEUR's parliamentary groups into one parliamentary group and to form them into an electoral cartel. They expected a victory of the Center-Left to attract the centrists from the former DC who were housed in Berlusconi's 
Polo. This component of the Popolari acknowledged that the third autonomous Polo they wanted to bring about would not reinvent the DC. Still, they hoped to create "an autonomous center," like the DC had been, and which, in Zecchino's words, "chooses every time. Like in Germany, where the Liberal party decides before the elections with whom to ally." 16

Many notables of the former DC, particularly Giulio Andreotti and Ciriaco de Mita, championed this position. Unwilling to step aside, and still a significant player in the Popolari's strongholds in the towns and villages of Campania and the South, De Mita sought to "reaggregate the Center." This, he believed, would attract the moderate voters who alternated between the impulse to abstain and the temptation to shift to the Right. In order to reach this goal De Mita emphasized the peculiar "mixture of values, habits, and interests that has long been identified with the DC and which has been crushed by the Left's weight." As a result, he criticized those who sought to unite all the centrist forces, except the DS. According to De Mita, Boselli's socialists, for example, "have a different history and destiny...The DS with the socialists, and the DC with the former DC." 17

The other strategy within the PPI was pro-Olive Tree. Unlike the Democrats, however, these Popolari did not want to create a single party. Instead, they argued for a reunification that would bring together not only the former DC Center, but also the diverse world of the "non DS" within the Center-Left. This strategy aimed to provide the Olive Tree's "second leg," beside the DS.

Mino Martinazzoli emerged as a convinced and articulate advocate of the Center's separate and autonomous existence, independent of the Left, within the coalition. Martinazzoli also claimed that rather than safeguarding the DC's political heritage so dear to De Mita, he wanted to protect and recast the values of popolarismo in the new political context. Speaking from the podium of DS's Lingotto Congress, the founder of the second PPI reminded his audience in January that the Olive Tree alliance need not, and in fact could not, "imagine its own future in the eclipse of the CenterLeft's Center." The Center, Martinazzoli argued, was indispensable in order to attract the support of "moderate social groups" away from the Polo. This was the PPI's more open, and culturally better equipped, component. It emphasized the coherence between inspirational ideals and political actions as well as the Popolari's "difference" and the value-added that their identity brought to the coalition. As Martinazzoli liked to say: "Ideas are not valued for what they make, but for what they cost."

Franco Marini, too, wanted to combine all the Center's components into a unique formation that would bring together the area 
outside the DS. Marini acknowledged that it would be unrealistic to believe that the PPI could, as he would have liked, take the lead in aggregating the coalition's center. Hence, he invited his friends within the party to think about something more than a simple "federation." Marini was convinced that the time had come to give birth to a "new political force: we, from the moderate, or centrist, area or from liberal-democratic reformism, must dare making the decisive choice ... We must move to a unique formation... and must do it soon." ${ }^{\prime 8}$ At the same time, Marini also sought to reassure those, like Zecchino, who feared Castegnetti wanted to dissolve the PPI into the Olive Tree. Perhaps, Marini said, the Secretary was indeed "a bit too much in love with Prodi." Still, he added, "at this particular juncture, after all that has happened, love that lasts can be downgraded to a small venal sin." In the same context, though, Marini also clearly confirmed - primarily with "his friend D'Antoni" in mind - that "in this phase" it was necessary to be "either on this side, or on the other." Hence, the third centrist pole or "other similar things" are only "tricks that create confusion and uncertainty among voters without attracting a single vote."19

\section{Two Unknowns: Di Pietro and D’Antoni}

Three actors animated the Center in the second half of the year: Antonio Di Pietro, Sergio D'Antoni, and the newly formed Margherita alliance. Di Pietro, the former leader of "Mani Pulite," reappeared on the national stage at the head of his own movement, a natural outcome of his divorce from the Democrats. Seeking to reposition himself in a more congenial segment of the political market, he no longer presented himself to his potential voters as an alternative centrist option located between the Polo and the Olive Tree. Instead, he proclaimed his faithfulness to the Center-Left bloc. To be sure, Di Pietro also stated he wanted his movement to stand for an "alternative pole" in the electoral system, but he claimed his goal was the same as that of the Olive Tree. Both wanted to defeat Berlusconi "whom we believe to be unreliable as a person and politically ineligible due to the triple conflicts of interest he carries with him." Di Pietro insisted that his contribution was absolutely necessary for Berlusconi's defeat. As he put it, "the Center-Left presently lacks sufficient" appeal to convince the majority of Italians to vote for the Left." The only way to win was to convince the majority of Italians not to vote for the Center-Right: "In order to stop Berlusconi the only possible - and anyway necessary - strategy consists of "draining" support from the other 
bloc's voters." Nobody, claimed Di Pietro, was better suited to this task than he himself. Nobody was more capable of shifting the balance of strength than the "outsider Di Pietro," who cast himself as the "container" that would attract "the vote of the discontented and of those who, for ideological or idiosyncratic reasons, would never vote for the Left." 20

By contrast, CISL Secretary D'Antoni, whose frequently announced and always postponed entry into politics eventually took place in the last months of the year, pursued a different goal. Preceded by a friendly TV interview, D'Antoni's self-anointed candidacy for political leadership took place on 12 October in Florence when he announced to the CISL executive committee that he was resigning from his post as the union's Secretary. D'Antoni entered the fray, thinking that the moment had come to try and overcome the bipolarism of Italian politics by giving birth to the Third Pole, for which a substantial component of the former DC had been yearning. At the same time, D'Antoni knew that without a new proportional law that replicated the German model, his project risked immediate failure. In fact, when D'Antoni appeared on the scene, only his personal ambitions were clear. Not much was known about his real intentions. Nor did anyone have a clear sense of the political positions of his yet-to-be-built foundation "Democrazia Europea." Throughout the year, D'Antoni moved in symbiosis with the entire large bloc that crosscut the center of the Center-Left. This bloc openly pursued a Third Force strategy that was in full keeping with the ideological legacy of the DC and the role it played during the First Republic. Political successes, he hoped, would enable him to build a new political party.

D'Antoni made his influence felt in Sicily, in the summer, where the CISL Secretary was widely perceived as the hidden architect of the maneuver that launched the Leanza administration. Not only did D'Antoni not deny this - "I am not part of it, but Leanza is okay," he declared instead - he also took a clear interest in the success of Palermo's "centrist laboratory." Successfully exported to the national level, this experiment could have cleared the space for a new center that would cross cut the two poles, and D'Antoni could have become its leader. ${ }^{21}$

Of course, those who advocated a Center-Left leaning Third Pole intensively courted D'Antoni. First among them was Mastella, who feared having to compete with him in Sicily and in the South. Franco Marini, too, though not a "Third Pole" advocate, invited D'Antoni to stay with the Center-Left, by suggesting he could become "the Margherita's spokesman," an option that clearly displeased Parisi. At the same time, Marini also criticized D’Antoni for 
wanting to use the union as the electoral underpinning of a political project aligned with the Center-Right. No CISL Secretary, said Marini, has ever "claimed to bend the organization to his own political goals" not only because union members "vote as they please," but also because, "no true union in Europe stands in the conservative camp." 22

By the end of the year, D'Antoni's political debut had been less disruptive than his supporters had wished. True, the Foundation had attracted, according to its promoters, roughly 50,000 supporters in a month, but these members came primarily from within the CISL. While the union's organizational resources supported the Foundation, a strong push for autonomy prevented the new Secretary, Savino Pezzotta, from enthusiastically supporting D'Antoni. ${ }^{23}$ Still, D'Antoni's initiative failed to move beyond Sicily, the home of "Democrazia Europea." Very few former Christian Democrats, now scattered among the PPI, UDEUR, CCD, CDU, showed any interest in uniting under the former CISL leader's flag. ${ }^{24}$ Only a few followers of Giulio Andreotti, who had long been confined to the political backstage, offered their unconditional support and endorsement. Even the early polls were discouraging for D'Antoni, and so by the end of the year his ambitions had apparently been downsized, and he was rumored to be considering running for mayor of Rome.

\section{Between an Electoral Alliance and a "New Political Subject:" the Margherita}

At the beginning of May, the small Center-Left groupings surrounding the DS scurried about seeking a way to relaunch the "center federation," the Olive Tree's so-called "second leg." Their moves and their purpose remained unclear and conflicts abounded. Mastella played the role of fireman, trying to keep his hands as free as possible, and Boselli adamantly rejected a "thing of the center," that was to be aggregated by former Christian Democrats. Still, there was apparent progress, because this drive was inevitably linked to the issue that captivated the entire CenterLeft: the choice of a Prime Ministerial candidate to lead the Olive Tree at the national elections. Even Di Pietro's departure from the Democrats was seen primarily as the disappearance of an obstacle. All that remained to be done, so it seemed, was to wait for the referendum on the majoritarian electoral system to fail. At that point, many of the Olive Tree's Centrists believed the "center federation" would become an imminent and unstoppable reality. 
At the beginning of June, the PPI leadership unanimously approved a report by Castagnetti. The Secretary proposed accelerating the "constitution" of the center of the Center-Left and initiating immediately (i.e., before the summer), the process through which the concerned organizations were to form a federation. He addressed the invitation to the UDEUR, the Rinnovamento Italiano and the Democrats.

In the end, the Democrats declined the invitation, viewing the aggregation it proposed as too limited, too confined to parties of Catholic origins, and, according to Parisi, too much at risk of recreating the DC. As a result, at the end of July in Rome, in an unlucky parallel with the "counter-quake" that was taking place in the Sicilian region, only the PPI, UDEUR and Rinnovamento met to create a new reformist center. Launching an alliance called, "Una scelta per L'Italia" (A Choice for Italy), they hoped to become the first stone in the building of the always wished for, and often announced, centrist federation. This was the first uncertain step that would lead, in September, to the most advanced unitary project agreed upon by the centrist galaxy, the Margherita, a fourmember alliance comprised of the PPI, UDEUR, RI and, at last, the Democrats too. ${ }^{25}$

Rutelli's designation as the candidate for Prime Minister pushed the Democrats to join the aggregation. As Parisi made clear in a September interview, the mayor of Rome appeared to be the Margherita's natural leader. Parisi maintained that the Democrats liked Rutelli because, with him, there was no chance that the alliance would appear or become "a confessional formation inspired by the PPI," in which they would not wish to participate. ${ }^{26}$ On Parisi's request, Rutelli also clarified his direct engagement in the Margherita, by heading the list for the seats to be assigned by proportional representation. Rutelli himself also needed the Margherita. This association offered more solid and broad organizational and political backing than did the Democrats. In fact, the mayor of Rome had been very active in launching the Margherita.

The Asinello's decision to join the new electoral alliance was announced in October, at the Assembly of Regions, and confirmed in December by the same body, after defeating minister Borodon's opposition. This endorsement suggested the possibility of a wider aggregation process that would remain underway with the objective of keeping the party's "doors open for new members, be they from the SDI, the Greens, or movements issued from civil society." The Democrats insisted that the long-term perspective was still a house for all reformists. In the meanwhile, however, the Margherita failed to set in motion the dissolution of its four founding parties, 
with the goal of moving towards organizational unity and, hence, a single party. The Margherita's leaders called it a "political subject," but no one knew precisely what that meant. ${ }^{27}$ What was known was that they would converge around a single list at the national elections, so that the 4 percent electoral threshold would not eliminate any centrist. In November, the first polling results released by the Margherita's founders credited it with a safe, but still modest 8.4 percent.

\section{To Conclude}

By the end of the year, unity remained an uncertain and distant goal. The Center risked becoming just a geographical point, without any specific political content or a shared long-term strategy. All the centrist political actors sought to enhance the Center's electoral clout, but at the legislature's end, and with Berlusconi at the door, this seemed hardly more than wishful thinking. The political and organizational "paths" advocated by the Center's various segments seemed to block and annihilate each other. The Margherita was, and clearly remained, little more than an electoral cartel, whose components, especially, but not only Prodi and Amato, displayed different political goals and fought each other. At the same time, the strategy of the UDEUR and part of the PPI to create a Third Pole, and thereby to rebuild "the new DC of the year 2000" clashed with the strategy of those - another part of the PPI, Rinnovamento Italiano among others - who wanted instead to consolidate the Olive Tree's Catholic and Liberal-democratic "second leg." Furthermore, there were also those who thought that the Center could not, under any conditions, do without the irreducible "specificity of the PPI." All three positions were threatened by the Asinello's "non negotiable" request: the strategy that consisted of forming "one party for all reformers" - an ambitious attempt to change forever the historical boundaries of the Italian party system, by unifying the Center and the Left. Unable to reform itself, the Center could only wait for the outcome of the anticipated national elections that would dictate a new organizational topography.

(translated by Serenella Sferza) 


\section{Notes}

1. In the end, the knot has been loosened: in November, at the first meeting of the Olive Tree's national coordination, it was "officially" decided to adopt the nonhyphenated version. See S. Messina, "E alla fine il pio Mastella scioglie il grande freddo", la Repubblica, 24 November 2000.

2. This percentage comes from adding the votes for the Democrats, PPI, UDEUR, SDI, Rinnovamento Italiano, PRI, Liberals in the provincial elections, and the Lista Cacciari in the Veneto, either alone in coalition.

3. By contrast, the other two Republican deputies (Luciana Sbarbati and Antonio Mazzocchin) opposed the turn toward the Polo and, especially Sbarbati, strongly fought against it.

4. The SDI's Secretary had rejected the personal offer made by the Polo's leader in Tunis at Craxis' funeral. Berlusconi had asked Boselli to join him. In so doing, he guaranteed that Boselli would have become, "the carnation in the Polo's button hole." Boselli's outspoken faithfulness to the Center-Left earned him a split led by the resurrected Claudio Martelli (a SDI Eurodeputy since 1999) and by Craxi's son (a defeated candidate at the European Elections) who, in those very days, gave birth to the "Lega dei Socialisti."

5. Martinazzoli's candidacy was embodied by a unitary "Martinazzoli-CenterLeft" list, another coalition SDI-Liberals-Others and Rifondazione Comunista list. Different from what happened in Lombardy, a wider array of local lists supported Cacciari. Next to a "Cacciari list," which the Democrats, PPI, RI and UDEUR joined, the DS, the Greens, the SDI-PRI, the Italian Communists and Rifondazione Comunista had maintained their "visibility."

6. The disillusionment came not only from the 31.5 percent of the ballots obtained at the regional elections, but also from the modest 20.5 percent it obtained at the provincial elections in which nearly all the Center-Left's components had merged behind the former mayor of Brescia.

7. Here, with 38.2 percent, Cacciari's candidacy had acted as a more effective magnet for the Center-Left.

8. The UDEUR was able to form an autonomus parliamentary group in the Chamber only on 13 December 1999, when two deputies from the Lega Nord and RI joined the eighteen deputies who had stayed in the UDR-Unione democratici per la Repubblica within the mixed group, since 30 June 1999, when the UDR had been dissolved because it fell below the twenty deputies threshold. At the beginning of 2000, Mastella's party had twenty-one deputies and eleven senators who became thirteen in the course of the year, and two ministers (S. Cardinale at Communication, and A. Loiero at regional Affairs) and six undersecretaries in the Amato government. The party chose as its President the former leader of the Lega Nord Irene Pivetti. By the end of the year, though, Pivetti was on a collision course with Mastella because of her opposition to the Margherita.

9. Regarding Cuffaro, see the article by S. Messina, "Totò, il regista dei ribaltoni100 mila voti senza nessuna tv," la Repubblica, 9 May 2000.

10. The Democrats were born officially on 5 February 1999, when Romano Prodi announced the formation of the political group "Democats for the Olive Tree." On 1 March, the movement's name was chosen, "the Democrats," as well as its symbol, a donkey kicking in a vaguely Disney-like style. Their electoral debut, at the June 1999 European elections, was brilliant: 7.7 percent of the votes, the second highest score among the Center-Left's formations. By the beginning of the year, the Democrats could rely on twenty-one deputies and five senators, 
who later on became six; they had four ministers - Bianco, De Castro, Bordon, Maccanico - and eight undersecretaries in the second D'Alema government. They went down to three ministers - Bianco, Bordon, Maccanico - and six undersecretaries in the Amato government, where their governmental representation shrank as a result of their bad performance at the regional elections (3.5 percent). The Democrats claimed - at the first "Assembly of the Regions" of 5-6 February $2000-88,712$ members, and had in their ranks the presidents of two Provinces, twenty-five regional councillors and roughly 2000 mayors.

11. See B.J. "Il PPI: costituente del Centro-"partiamo anche senza Parisi", la Repubblica, 2 June 2000. As Parisi himself was to admit, however, the referenda - a source of many significant disagreements - were an additional and immediate obstacle to the union of all reformists, not to mention all the proOlive Tree components. The Democrats, for example, in keeping with their bipolar vocation, advocated a yes-vote, not only on the referendum that proposed to abolish the electoral system's proportional quota, but also on the ones that would have abolished the public financing of parties and the automatic withdrawal of Union membership fees from members' paychecks.

12. B.J.,"Il PPI: costituente del Centro-"Partiamo anche senza Parisi," la Repubblica, 2 June 2000.

13. B. Jerkov,"E' rissa nei Democratici tra parisiani e dipietristi," la Repubblica, 6 May 2000. With thirty-nine yes, seven no and four abstentions, in addition to Di Pietro, who had already resigned, the Assembly of the Regions decided to expel the two deputies who supported him, Gabriele Cimadoro and Elio Veltri, both of whom had voted against the Amato government in the Parliament.

14. See the interview with the minister, "Zecchino: il partito e' finito-saremo una costola dei DS,” la Repubblica, 18 March, 2000. Even the party’s former Secretary, Geraldo Bianco, fiercely attacked Castagnetti for his perceived surrender to Bassolino concerning the candidacy to the presidency of the Campania region and the problems that surrounded the formation of the regional administration.

15. In addition, there were four European deputies. In the second D'Alema government, the PPI had five ministers: Mattarella as minister of Defense, Letta as minister of Industry, Rosi Bindi as Health minister, Zecchino as University minister, Patrizia Toia as minister of Community policies, and twelve undersecretaries. In the Amato government the Popolari's presence in the executive shrank to four ministers (Bindi, the minister of Health, fell) and eleven undersecreataries. Until the 16 April regional elections, the PPI had five presidents of regions and eighty-seven regional councillors, to whom one should add thirty presidents of provinces and 331 provincial councillors. Overall, the PPI claimed 195,612 members.

16. In the interview by F. Saulino, "Berlusconi ha ragione, cosi' il PPI sparisce," Corriere della Sera, 26 August 2000.

17. See De Mita's interview by S. Marroni, "De Mita seglie Rutelli “ con lui ce la giochiamo," la Repubblica, 17 September 2000.

18. From the interview with Franco Marini, former PPI's Secretary, by S. Messina, "Un partito unico di centro contro i rischi di egemonia DS," la Repubblica, 23 January 2000.

19. See Marini's interview by A. Caporale, "Castagnetti non si discute, ma serve una nuova squadra," la Repubblica, 30 August 2000.

20. All the citations of Di Pietro are drawn from the letter he sent to la Repubblica, and published on 13 October 2000, with the title "La sinistra e' cieca. Io tolgo voti a destra." 
21. "Clearly, were the attempt to give the Region a government of all centrists from Forza Italia, CCD and CDU to parts of PPI, Udeur and Rinnovamento Italiano - leaving out An (which, could provide external support) and the Left, to succeed, it would be a nice window for the projects that are inspired by the PPE - a "Center that looks to the Right" which D'Antoni would like to export to the national level." B. Jerkov, "D’Antoni fa le prove generali nel laboratorio di Palermo," la Repubblica, 14 July 2000.

22. See M. Calabresi , "No ai Poli, nasce il Centro"-ecco il piano di D’Antoni," la Repubblica, 7 October 2000.

23. Those signs of support were also relatively meaningless, since membership was free according to press reports, see a. cap., "Un vecchio padre nobile per un leader virtuale,” la Repubblica, 19 November 2000.

24. I am referring here to the incarceration for mafia-related reasons of a Catania municipal councillor who had just jumped ship from UDEUR to Democrazia Europea. See M. Giuffrida, "Catania, manette al medico-consigliere," la Repubblica, 19 November 2000.

25. In the meantime, on 17 June, the new name of the Center-Left electoral alliance, The Olive Tree-Together for Italy, had been announced. The name was meant to please both those who wanted to keep a reference to the past and those who wanted to mark its "novelty" with respect to the 1996 Olive Tree.

26. B. Jerkov, "Nasce il centro Margherita," la Repubblica, 11 September 2000. "Rutelli is the hinge around which the unification process is rotating. "The two issues are distinct, but naturally intertwined," acknowledges Parisi." Ibid.

27. Especially in the mind of its most devoted advocates, the Popolari's pro-Olive Tree wing -for whom the Margherita is already worth, with its initial four petals, "more than the 12 percent people are talking about" - the Margherita was to become a "new political subject," one of the Olive Tree's two souls, which itself was to be the "synthesis between Left, liberalism, democratic Catholicism and environmental culture." This is according to Bindi, in her interview with D. Gorodisky, "Bindi: con Francesco una squadra, dico no a un vice dei DS,” Corriere della Sera, 28 September 2000. 